\title{
HUMAN PERFORMANCE IMPROVEMENT IN THE HEALTH CARE ORGANIZATIONS. RESULTS OF EMPIRICAL STUDY IN POLAND
}

\author{
Katarzyna SZCZEPAŃSKA*, Małgorzata WIŚNIEWSKA** \\ * Warsaw University of Technology, Faculty of Management, Department of Qualitology, Poland \\ e-mail: k.szczepanska@wz.pw.edu.pl \\ ** University of Gdansk, Faculty of Management, Department of Economies of Enterprises, Poland \\ e-mail: wis@wzr.pl
}

\begin{abstract}
Human Performance Improvement (HPI) as well as human aspects in Quality Management (QM) has received strong attention from researches. Many studies investigate the level of health care services and their main determinants. This paper seeks the relationships between the concepts of HPI and QM. The aims are to present the HPI practices on the example of EFQM Business Excellence Model criteria. HPI criteria were measured by EFQM model in Health Care Organizations (HCO) in Poland with use of case study methodology conducted on the basis of self-assessment reports documentation. The study included all HCO which are Polish Quality Award winners in the years 2005-2010. Studied HCO belonged to public sector. Results of study: (1) showed that the rules of HPI apply to all criteria of the EFQM model in Human Resources Management range, (2) justified the role and importance of HPI in the evaluation QM in HCO. The use of the EFQM model to assessment of the quality level of HCO is helpful for implementation of aimed improvement. Building QM awareness contributes to HCO creation of the need for management mechanisms and the development of medical service personnel function which is related to HPI.
\end{abstract}

Key words: Human Performance Improvement (HPI), Quality Management (QM), EFQM Business Excellence Model.

Introduction

Implementation of quality principles in health care organizations (HCO) as well as their improvement is necessary for the growth of patient satisfaction. A number of studies have suggested that "approximately $30 \%$ to $40 \%$ of the patients do not receive necessary care according to current scientific evidence and $20 \%$ to $25 \%$ of care provided has been medically unnecessary and potential harmful" [2, p. 4]. Improvement should be understood as an action intended to achieve excellent state, which is expressed in the organization's objectives. In this context, the importance of assume Quality Management (QM) has the principles defined by the European Foundation for Quality Management (EFQM), which include: [16, p. 26]:

- achieving balanced results,

- adding value for customers,

- leading with vision, inspiration and integrity,

- managing by process,

- succeeding through people,

- nurturing creativity and innovation,

- building partnership,

- responsibility for a sustainable future.
With regard to human resources management (HRM), these principles are the basis of high - performance work system (HPWS), which is oriented to achieve better reliability, safety and performance. HPWS is define as "integrated set work practices result in that engaged employees and positive individual, unit, or organizational level outcomes" [4, p. 38]. The structure of HPWS has evolved from QM and HRM theory and is related to Human Performance Improvement (HPI), which is mostly defined as "a systematic approach to identification, pointing at and implementation of solutions eliminating the barriers which make the execution of work difficult and which are done in a way that is effective so characterized by a positive (desirable) result (...). The rules of HPI concept are: orientation on the results of activities, concentration of work effects, system approach" [17, pp. 194-195]. The use of HPI concepts in management practice requires a change in thinking about people and their work. On the other hand, is subject to the store of knowledge about the impact of the effects of workers on the results achieved by the organization. 
Table 1. Factors of quality in health services

(source: own research based on $[15, p .57]$ )

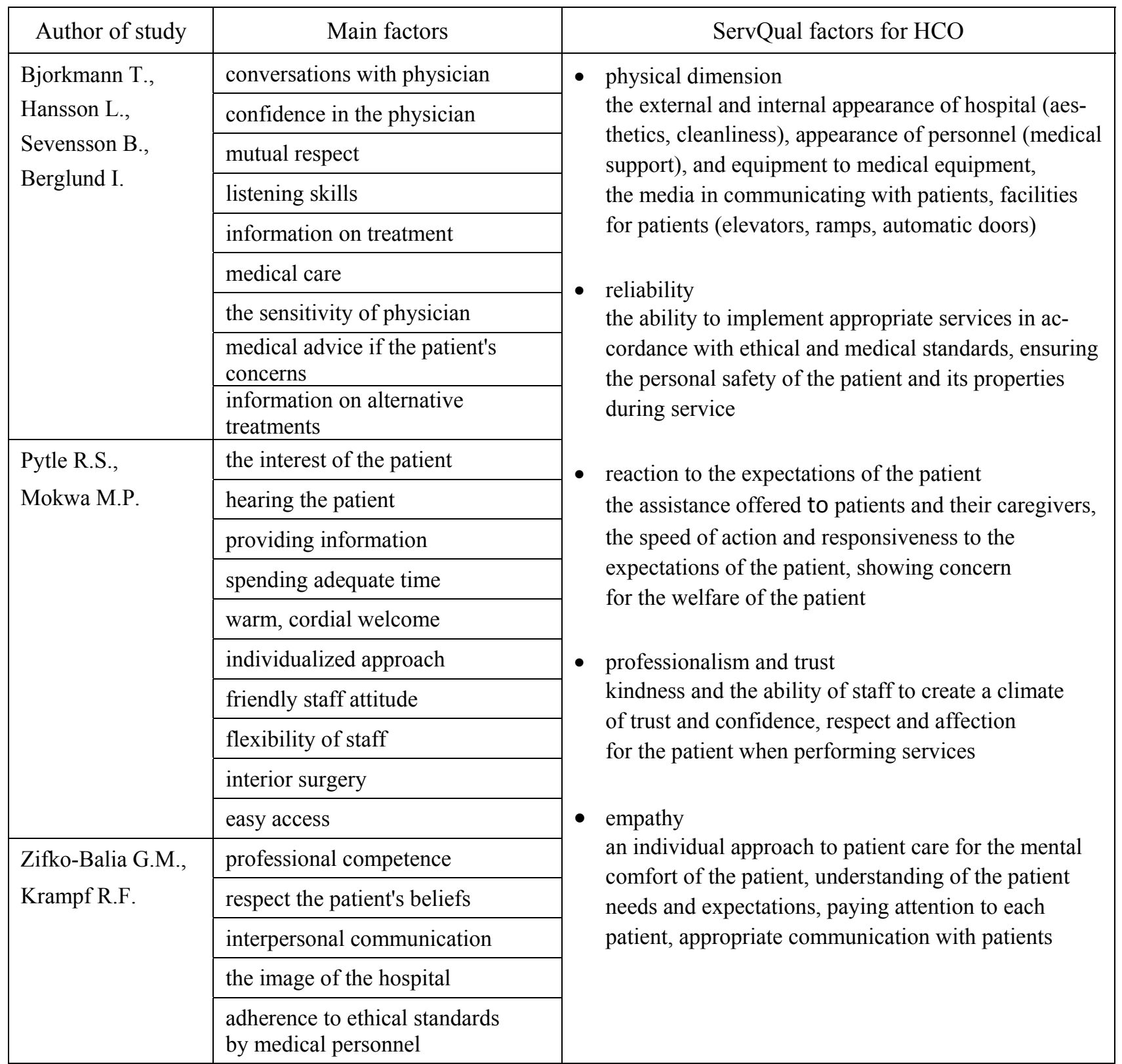

A synthetic measure might be their customer satisfaction index, calculated on the basis of research results, mostly surveys. „A new generation of patient satisfaction studies investigates how patients combine their attribute reactions to arrive their overall satisfaction" [11, p.117]. The factors influencing patients' perceptions of quality health services are presented in Table 1. Most of the presented factors refer to the relation physician-patient. In minority are factors relating to the relationship nursing care-patient and environmentpatient. This set might rank the factors affecting patient satisfaction with medical services. The systematic measurement allows determining the level of excel- lence of health care services. Therefore constitutes the value provided to patients. The application of HPI model into HRM practice "helps in the achievement of improvement aims by identifying the fields which require improvement and the design of effective and efficient improving activities" [7, p. 14]. The concept of improvement requires parameterization of activities in the field of HRM. It makes it necessary to use a structure of qualitative and quantitative measurers in all the elements of personnel subsystem of a company. The relationships between elements of HPWS with rules of HPI and QM are presented in Table 2. 
Table 2. HPWS, HPI and QM rules

(source: own research based on: [4, pp. 40-41])

\begin{tabular}{|c|c|c|c|}
\hline $\begin{array}{l}\text { Authors } \\
\text { of the study }\end{array}$ & Names of HPWS* practices & HPI**rules & $\begin{array}{l}\mathrm{QM}^{* * *} \text { rules/ } \\
\text { HPI rules }\end{array}$ \\
\hline \multirow{6}{*}{$\begin{array}{l}\text { West et al. } \\
\text { (2002) }\end{array}$} & centralization & results of activities & \multirow{11}{*}{$\begin{array}{l}\text { - achieving balanced results, } \\
\text { - leading with vision, inspiration } \\
\text { and integrity, } \\
\text { - responsibility for sustainable } \\
\text { future } \\
\text { (results of activities) }\end{array}$} \\
\hline & performance appraisal & system approach & \\
\hline & sophistication of training & concentration & \\
\hline & teamwork & of work effects & \\
\hline & training needs & & \\
\hline & training policy & & \\
\hline \multirow{9}{*}{$\begin{array}{l}\text { Boselie et al. } \\
\quad(2003)\end{array}$} & employee training & \multirow{5}{*}{$\begin{array}{l}\text { concentration } \\
\text { of work effects }\end{array}$} & \\
\hline & participation in seminars & & \\
\hline & skill development & & \\
\hline & direct supervision & & \\
\hline & teamwork & & \\
\hline & employee influence & \multirow[t]{4}{*}{ system approach } & \multirow{14}{*}{$\begin{array}{l}\text { - adding value for customers, } \\
\text { - managing by processes, } \\
\text { - building partnership } \\
\text { / } \\
\text { (system approach) }\end{array}$} \\
\hline & employee participation & & \\
\hline & quality control & & \\
\hline & reward system & & \\
\hline \multirow{10}{*}{$\begin{array}{l}\text { Harmon et al. } \\
\quad(2003) \\
\text { Scotti et al. } \\
(2007,2009)\end{array}$} & alignment & \multirow{5}{*}{$\begin{array}{l}\text { concentration } \\
\text { of work effects }\end{array}$} & \\
\hline & information & & \\
\hline & teamwork & & \\
\hline & trust & & \\
\hline & creativity & & \\
\hline & development & \multirow[t]{4}{*}{ system approach } & \\
\hline & involvement & & \\
\hline & empowerment & & \\
\hline & performance - based rewards & & \\
\hline & performance enablers & results of activities & \\
\hline \multirow{6}{*}{$\begin{array}{l}\text { Preus } \\
(2003)\end{array}$} & employee scientific knowledge & \multirow{3}{*}{$\begin{array}{l}\text { concentration } \\
\text { of work effects }\end{array}$} & \multirow{16}{*}{$\begin{array}{l}\text { - succeeding through people, } \\
\text { - nurturing creativity and innova- } \\
\text { tion } \\
\text { (concentration } \\
\text { of work effects) }\end{array}$} \\
\hline & $\begin{array}{l}\text { employee experience - based } \\
\text { knowledge }\end{array}$ & & \\
\hline & employee involvement & & \\
\hline & $\begin{array}{l}\text { work design for low - skilled } \\
\text { workers }\end{array}$ & \multirow[t]{3}{*}{ system approach } & \\
\hline & $\begin{array}{l}\text { work design for high }- \text { skilled } \\
\text { workers }\end{array}$ & & \\
\hline & process templates & & \\
\hline \multirow{10}{*}{$\begin{array}{l}\text { Rondeau and } \\
\text { Wagar } \\
(2006)\end{array}$} & employee suggestion system & \multirow{7}{*}{$\begin{array}{l}\text { concentration } \\
\text { of work effects }\end{array}$} & \\
\hline & quality improvement teams & & \\
\hline & self - managing teams & & \\
\hline & employee attitude surveys & & \\
\hline & flexible work hours & & \\
\hline & job enrichment/job enlargement & & \\
\hline & self-scheduling & & \\
\hline & shared governance & \multirow[t]{3}{*}{ system approach } & \\
\hline & incentive - based/merit pay & & \\
\hline & employee recognition system & & \\
\hline
\end{tabular}

* HPWS: High - Performance Work System

** HPI - Human Performance Improvement

*** QM - Quality Management 
As the table shows all HPWS practices are strongly associated with the HPI rules, which relate directly to the principles of QM. It should also be noted that most of HPWS practices is associated with the function of training in HRM and work organization. According to the criterion of level management, analyzed practices relate to a greater degree of operational management in HRM (e.g. control, budgeting, control effectiveness and efficiency of training). To include the strategic HRM practices, they related to personnel policy and strategy (e.g. training policy, empowerment). Through relationships with QM, principles HPI can be the basis for determining personnel strategies to improve the resulting actions. The analysis confirms that HPWS ,aligns with other aspects of the organization, such as strategy (...), systems view of an organization (...). Valuable practices should be viewed as best practices and that more practices should be linked with positive outcomes" [4, p. 44]. This represents cohesion of QM with HPI. To answer the question, which of the practices are commonly used by $\mathrm{HCO}$ for assurance high quality services and achievement high patient satisfaction make possible the assessment of achievements in the HPI. One possibility is self-assessment according to criteria of EFQM Business Excellence Model, which is based on the principles of QM.

\section{2}

\section{Business Excellence Model for health care organizations}

Models of excellence are used to assess the level of excellence in QM including the aspect of HRM. It is worth noting, that there is observed a certain kind of unwillingness in public sector to implement EFQM Model of Excellence. Preferred model is CAFCommon Assessment Framework, specific and adapted for public organizations, including public HCO. It is based on the premise that excellent results in organizational performance, citizens/customers, people and society are achieved through leadership driving strategy and planning, people, partnerships and resources and processes. It looks at the organization from different points of view at the same time and represents the holistic approach of organization performance analysis. The CAF model consists of 9 criteria and 28 subcriteria. Each criterion of the CAF model is assessed by considering a number of sub-criteria on the basis of specific scoring system.
The overall structure of the model CAF forms two groups of criteria:

- enablers (including leadership, policy and strategy, people, partnership and resources, processes),

- results (including customer results, people results, society results, key performance results).

CAF model in the perspective of HPI refers mainly to the following criteria: leadership, employees, business performance in its relations to the publics - clients (patients) and in relations with employees. This allows study the level of excellence in the organization from the external and internal perspective. As it was mentioned earlier, the basic tool of Business Excellence Model (BEM) is the self-assessment. Organizations should demonstrate the evidences of the fulfillment of the criteria. They can be synthetic descriptions of practices and numerical data (indicators, statistics), showing their implementation and results (effects). They are the basis for carrying out the scoring level of excellence. It can be assumed that achievements of winners of BEM might be a kind of benchmark parameter. „Benchmarking between organizations is often practiced through the use of performance indicators, which are defined as measurable aspects of care which give an indication of quality, safety, efficiency and accessibility" [3, p. 24]. Best practices also allow determine the directions and areas of quality services improvement in $\mathrm{HCO}$.

The most popular business excellence scheme in Poland is Polish Quality Award (PQA). It was established in the 1995 by following organizations: the Quality Committee of the National Chamber of Commerce, the Polish Research and Certification Centre and the Foundation "Teraz Polska". As every national quality award in Europe, it is based on the EFQM model of excellence. The prize of PQA is dedicated to all Polish companies that, through the implementation of QM philosophy, have achieved an increase of customer satisfaction, employees and business performance. Model CAF covered by PQA has the same structure of criteria as the CAF model covered by EFQM. From 1995 to 2010 PQA winners were 60 enterprises. In the great majority $(63 \%)$ were the winners of manufacturing and service companies (public organizations were $34 \%$, and only $3 \%$ educational). 
Table 3. Description of the category and leadership practices

(source: own study)

\begin{tabular}{|c|c|c|}
\hline \multirow{2}{*}{ HPI rules } & Criterion $\mathrm{CAF}$ & Health care organizations $(\mathrm{HCO})-$ winners of PQA \\
\hline & Leadership & Number of practices \\
\hline \multirow[t]{4}{*}{ system approach } & $\begin{array}{l}\text { development, prevalence } \\
\text { vision and mission }\end{array}$ & $\begin{array}{l}\text { - } 1 \text { respondent has correctly identified the vision and mission } \\
\text { - } 3 \text { respondents have identified the mission, however haven't } \\
\text { identified the vision } \\
\text { - } 1 \text { respondent has identified the vision however hasn't identified } \\
\text { the mission }\end{array}$ \\
\hline & $\begin{array}{l}\text { translating the vision and } \\
\text { strategic objectives into } \\
\text { operational objectives and } \\
\text { actions }\end{array}$ & $\begin{array}{l}\text { - } 4 \text { respondents have not defined objectives } \\
\text { - } 1 \text { respondent has stated the specific objectives (Balanced Score } \\
\text { Card) }\end{array}$ \\
\hline & $\begin{array}{l}\text { enabling stakeholders in } \\
\text { the process of setting goals } \\
\text { and develop strategies }\end{array}$ & $\begin{array}{l}\text { - } 3 \text { respondents have not described how they contribute } \\
\text { to the development strategy } \\
\text { - } 2 \text { respondents did not provide data }\end{array}$ \\
\hline & $\begin{array}{l}\text { creating a network of rela- } \\
\text { tionship and partnership }\end{array}$ & $\begin{array}{l}\text { - } 3 \text { respondents have co-organized preventive programs, } \\
\text { - } 1 \text { respondent has signed cooperation agreements } \\
\text { with other national hospitals } \\
\text { - } 1 \text { respondent has signed cooperation agreements with foreign } \\
\text { hospitals }\end{array}$ \\
\hline \multirow[t]{7}{*}{$\begin{array}{l}\text { concentration } \\
\text { of work effects }\end{array}$} & $\begin{array}{l}\text { contribute to the develop- } \\
\text { ment organization's man- } \\
\text { agement system }\end{array}$ & $\begin{array}{l}\text { - all of respondents are characterized by the formal leadership } \\
\text { and commitment }\end{array}$ \\
\hline & $\begin{array}{l}\text { communicating vision } \\
\text { and strategy at all levels } \\
\text { of the organization }\end{array}$ & $\begin{array}{l}\text { - } 2 \text { respondents used direct formal communication } \\
\text { - } 3 \text { respondents did not provide data }\end{array}$ \\
\hline & $\begin{array}{l}\text { encourage and support } \\
\text { activities related to learn- } \\
\text { ing and use the results of } \\
\text { these activities in the } \\
\text { management }\end{array}$ & $\begin{array}{l}\text { - } 1 \text { respondent was engaged in organizing scientific conferences } \\
\text { on management and health economics } \\
\text { - } 2 \text { respondents participated in seminars on medical issues } \\
\text { - } 3 \text { respondents did not take action }\end{array}$ \\
\hline & $\begin{array}{l}\text { stimulating and encourag- } \\
\text { ing the transfer } \\
\text { of entitlements }\end{array}$ & $\begin{array}{l}\text { - } 2 \text { respondents have delegated responsibilities, authority } \\
\text { and responsibility (job descriptions) } \\
\text { - } 1 \text { respondent had self-designated rules for decision-making by } \\
\text { employees } \\
\text { - } 2 \text { respondents had no delegated entitlements }\end{array}$ \\
\hline & $\begin{array}{l}\text { financing activities } \\
\text { in the field of learning } \\
\text { and improvement }\end{array}$ & $\begin{array}{l}\text { - } 4 \text { respondents have fixed the budget } \\
\text { - } 1 \text { respondent has no budget fixed ( ongoing financing } \\
\text { of all activities) }\end{array}$ \\
\hline & $\begin{array}{l}\text { helping employees } \\
\text { to achieve their plans } \\
\text { and to achieve objectives }\end{array}$ & $\begin{array}{l}\text { - } 1 \text { respondent used flexible working hours policy, provided finan- } \\
\text { cial support (post-graduate studies, medical specialties) }\end{array}$ \\
\hline & $\begin{array}{l}\text { understanding and re- } \\
\text { sponding to needs } \\
\text { of employees }\end{array}$ & $\begin{array}{l}\text { - } 2 \text { respondents held regular meetings with management } \\
\text { - } 3 \text { respondents conducted meetings with heads } \\
\text { of hospital departments divisions (unknown frequency) } \\
\text { - all respondents did not provide results of the meeting } \\
\text { (the findings or decisions) }\end{array}$ \\
\hline \multirow[t]{2}{*}{$\begin{array}{l}\text { results } \\
\text { of activities }\end{array}$} & $\begin{array}{l}\text { recognition of individual } \\
\text { and team efforts }\end{array}$ & $\begin{array}{l}\text { - all respondents had no formal rules-the immediate superior } \\
\text { decides }\end{array}$ \\
\hline & $\begin{array}{l}\text { implementation of systems } \\
\text { of rewards and incentives }\end{array}$ & $\begin{array}{l}\text { - } 1 \text { respondent had motivational system } \\
\text { - } 3 \text { respondents had applied bonus rules }\end{array}$ \\
\hline
\end{tabular}


3

Methods

The study included all $\mathrm{HCO}^{1}(\mathrm{~N}=5)$ which are PQA winners in the years 2005-2010. Studied HCO belonged to the public sector. Evaluation of their level of excellence has been carried out with the following criteria of CAF model: leadership, employees, business performance in relations with employees and customers - the citizens (patients). The study was conducted on the basis of competition documentation - HCO's self-assessment reports. The analysis includes only those criteria of CAF model, which have been described in the self-assessment model and directly related to HRM. The following hypotheses are examined:

Hypothesis 1: Effective leadership determines the use of quality management principles in HRM.

Hypothesis 2: HRM practices enable the realization of the principles of HPI.

Hypothesis 3: Results achieved by HCO in relations with employees are essential of activities for the HPI.

Hypothesis 4: Based on the measurements indicators showing better reliability, safety and performance in $\mathrm{HCO}$.

\section{$4 \quad$ Findings}

\subsection{Leadership}

The leadership criterion should provide evidence of how leaders:

- trace out the directions of the organization through the mission, vision and values,

- develop and implement a system for managing the organization, its actions and change,

- motivate and support people in the organization and inspire them by example.

As studies have shown starting with a project dominant approach and transitioning to a strategy or cultural approach produces the greatest continuous quality improvement outputs [1, pp. 283-293]. In CAF model, there are 14 specific criteria, which in the category of leadership allow assess the foundations of continuous quality improvement outputs. List of 13 practices identified in the HCO in the category of leadership with the HPI rules is shown in Table 3.

\footnotetext{
${ }^{1}$ Classification of hospitals in Poland is different from Europe, therefore assumed name HCO.
}

As is apparent from the practice the HPI is strongly associated with the category of leadership. In the studied HCO, leadership is largely a formality, which is not sufficient to improve the quality of health care services. By analyzing the orientation of the leaders $\mathrm{HCO}$ on the concentration of work effects can be said that only $50 \%$ has its base. This is insufficient because „approach, in which leaders empower frontline clinical providers to assist in development of important care processes, should increase not only quality of patient care and work quality but patient safety as well. Managers need to pay attention to how organizational policies and practices are perceived among front line care providers" [14, p. 342]. Important role of the leaders is also implementing knowledge-building practices as the creation of new knowledge resources.

In the studied $\mathrm{HCO}$, there was no common practice of leaders in this field. Only a small group of leaders participated in seminars and symposia on medical issues. The study showed no evidence of dissemination of knowledge among employees. There were no conditions for a system approach in most of the HCO. No basis (mission, vision) reduces the formation of an effective strategy. Its absence prevents the use of coherent control and evaluates the effectiveness of workers, work design and a systematic approach to the empowerment of employees. As the results of research an empowered work force will create greater outcome gains than the effects of specific team process improvement alone [1, pp. 283-293]. No strategy also makes it difficult to create relationships and partner network, which surveyed $\mathrm{HCO}$ practices are limited mainly to prevention programs for local communities. Most respondents of $\mathrm{HCO}$ cited that there was no motivation system and the system of recognition of individual and team achievements. Therefore cannot be measured the achievement of results of activities in HRM. There is also a lack of advisory bodies in the organizational structure of the HCO's. The necessity of their existence is confirmed by results of studies, which show that „hospital boards to improve their oversight of quality of care and patient safety, including taking such actions as establishing a board quality committee and developing strategic goals, specific to quality performance" $[5$, p. 146]. It must be stated that there were no in surveyed HCO:

- established guidelines for leadership to enhance mutual trust and respect in relations with employees, 
- electronic communication, which limits the effectiveness of forms of communication (vertical, horizontal),

- activities to promote an organizational culture focused on the example of welfare of patient, teamwork, respect,

- studies of the impact of leadership on the internal (e.g., processes, personnel, ethics) and external (patient satisfaction, image, market share of medical services) environment.

In none of the cases, there was no application of the quality program for health care services associated with the strategy. The research found that "effective leadership has been shown to enhance health care quality programs and likewise, quality management initiatives are reported to have positive impact on patient safety and other health care organizational outcomes" $[6$, p. 130]. It can be concluded that quality improvement in leadership category outputs indicates the low level of leadership and applying the principles of QM and HPI. Therefore, the first hypothesis was confirmed.

\subsection{People}

Strategy and personnel policy is the basis for implementation of activities aimed at HPI. The possibility of achieving the strategic objectives also depends on HPWS, which should be supported by proper implementation of personnel functions (e.g., motivating, rewarding, and training). Not without significance is the concern for the environment because "hospital work environment not only influences staff variables such as satisfaction and turnover but also influences the ability to provide high quality and safe care to patients" [14, p. 334]. In criterion "People" must be demonstrated evidence of how the organization:

- plans, manages and develops human resources strategy and planning,

- defines, develops and uses the skills of employees by adjusting the individual and organizational objectives,

- involves employees by development of dialogue and empowerment.

The CAF model has the 10 specific criteria, which in the category of people allow the assessment of continuous quality improvement foundations outputs.
The statement of eight practices identified in the $\mathrm{HCO}$ in this category with the HPI rules is presented in the Table 4.

The table shows that the majority $(75 \%)$ of the data refers to the concentration effects of work in the HPI. There are no data confirming the relationship with the principle - results of activities. Most respondents did not have HRM policies. The lack of this specific document identified in the form of personnel policy has also been described in the results of other studies related to HCO in Poland. They "did not confirm the existence of such a document in any of them in Podlaskie voivodeship (...). More than $28 \%$ of respondents were convinced that the personnel strategy in the form of a document does not exist, $14 \%$ had no opinion and $58 \%$ was sure that it did not exist in their institution" [8, pp. 73-74]. All investigated HCO declare that their managers have informed employees about principles of HRM, however there is no evidence for the communication of information to employees. Conditions of employment and salaries are generally not flexible. Therefore it can be stated that the surveyed HCO may not have sufficient system approach to quality improvement in people category outputs. The participation of workers in identifying goals does not occur in $80 \%$ of HCO's. The management imposes goals. Since the share of workers in the task forces is not voluntary (100\% of responses), the achievement of group objectives by employees is limited. This is a negative phenomenon, because „physicians involvement on clinical process improvement teams early in the program is essential for continuous quality improvement success" [1, pp. 283-293].

No HCO does not analyze training needs in order to ensure adequate competence of employees and does not plan the structure of human resources. However, $80 \%$ surveyed HCO created training plans based on staff reports, with only $20 \%$ that have developed training regulations. Implementation of training plans and training to enable workers to gain professional experience declare $5 \mathrm{HCO}$, but there are no numerical data confirming the plan and concerning other forms of education and work experience (post-graduate studies and job placement). This prevents the assessment of the foundations satisfying the health needs of patients. There is also formalized information considering the training. In $2 \mathrm{HCO}$ employees can obtain information only in the HR office. 
Table 4. Description of practice in the category - people (source: own study)

\begin{tabular}{|c|c|c|}
\hline \multirow{2}{*}{ HPI rules } & Criterion CAF & Health care organizations $(\mathrm{HCO})-$ winners of PQA \\
\hline & People & Number of practices \\
\hline \multirow[t]{2}{*}{ system approach } & $\begin{array}{l}\text { develop and prevalence } \\
\text { policies and principles } \\
\text { of HRM }\end{array}$ & $\begin{array}{l}\text { - } 2 \text { respondents identified the personnel policy } \\
\text { - } 3 \text { respondents had no formal personnel policy }\end{array}$ \\
\hline & $\begin{array}{l}\text { introduce the flexibility } \\
\text { in salaries and em- } \\
\text { ployment conditions }\end{array}$ & $\begin{array}{l}\text { - } 2 \text { respondents introduced contracts as a form of employment } \\
\text { - } 2 \text { respondents identified specific criteria for granting a bonus } \\
\text { for employee performance (no reference to the teams) } \\
\text { - } 1 \text { respondent had not undertaken any solutions }\end{array}$ \\
\hline \multirow[t]{7}{*}{$\begin{array}{l}\text { concentration of } \\
\text { work effects }\end{array}$} & $\begin{array}{l}\text { encourage employees to } \\
\text { evaluate managers }\end{array}$ & $\begin{array}{l}\text { - } 3 \text { respondents carried out once a year a formal evaluation } \\
\text { (questionnaire survey) } \\
\text { - } 2 \text { respondents had no results of the assessment }\end{array}$ \\
\hline & $\begin{array}{l}\text { develop and implement } \\
\text { a policy to ensure equal } \\
\text { treatment of all groups } \\
\text { and individuals }\end{array}$ & $\begin{array}{l}\text { - all respondents declared in the rules of work lack any form } \\
\text { of employment discrimination } \\
\text { - } 3 \text { respondents investigated the dynamics of the employment } \\
\text { of disabled persons and foreign nationalities }\end{array}$ \\
\hline & $\begin{array}{l}\text { create and communicate } \\
\text { the principles of train- } \\
\text { ing }\end{array}$ & $\begin{array}{l}\text { - } 4 \text { respondents had no formal training plans } \\
\text { - } 1 \text { respondent had only the regulations of training }\end{array}$ \\
\hline & $\begin{array}{l}\text { implement the training } \\
\text { plans and training to } \\
\text { enable employees and } \\
\text { work experience }\end{array}$ & - all respondents declared the implementation \\
\hline & $\begin{array}{l}\text { provide workers with } \\
\text { information about train- } \\
\text { ing opportunities }\end{array}$ & $\begin{array}{l}\text { - } 1 \text { respondent published the guides of training } \\
\text { - } 2 \text { respondents informed about training (available in HR) } \\
\text { - } 1 \text { respondent published information on an internal website } \\
\text { - } 2 \text { respondents informed about training in meetings with heads } \\
\text { of hospital departments divisions }\end{array}$ \\
\hline & $\begin{array}{l}\text { set the objectives to- } \\
\text { gether with the employ- } \\
\text { ees and review the } \\
\text { implementation of tasks }\end{array}$ & $\begin{array}{l}\text { - } 1 \text { respondent set with workers operational objectives and reviewed } \\
\text { the tasks on the basis of indicators during the regular meetings }\end{array}$ \\
\hline & $\begin{array}{l}\text { promote team work, } \\
\text { create task forces }\end{array}$ & $\begin{array}{l}\text { - all respondents appointed by a decision of management task forces } \\
\text { - workers' participation is not voluntary }\end{array}$ \\
\hline
\end{tabular}

Similar are conclusions of results of other studies in the Polish HCO - ,20\% of respondents pointed at the lack of system approach to trainings which in their opinion were only occasional and organized at random" [7, pp. 73-74]. A positive phenomenon is the conducting by three HCO formal assessment of the management carried out by employees and that all examined HCO declare no discrimination in employment.

Generally can be concluded that in the analyzed criterion there is a low quality improvement in health care services outputs. HRM practices of HCO significantly limit the implementation of the principles of HPI. The results of research did not confirm the hypothesis 2.

\subsection{Results of the activities in relations with the employees}

Results of the HPI activities in the internal dimension refer to organizational performance achieved in relations with employees. They can be measured by the level of satisfaction (overall index), degree of employee involvement, performance evaluations of employees, fluctuations and level of sickness absence (specific indicators). Achievements of the organization relating to the results of measurements of satisfaction and motivation of employees and other measurements of relationships with employees should be obtained by the self-assessment evaluation of this criterion. 
Table 5. Description of practice in the category results of the activities in relations with the employees (source: own research)

\begin{tabular}{|c|c|c|}
\hline \multirow{2}{*}{ HPI rules } & Criterion CAF & $\begin{array}{l}\text { Health care organizations (HCO) } \\
\text { - winners of PQA }\end{array}$ \\
\hline & $\begin{array}{c}\text { Results of the activities in relations with } \\
\text { the employees }\end{array}$ & Number of practices \\
\hline system approach & $\begin{array}{l}\text { employees' opinions about the: } \\
\text { - creation and realization of values, mis- } \\
\text { sion, vision, policy and strategy; } \\
\text { - communication, delegation of powers, } \\
\text { equal opportunities, express recognition, } \\
\text { involvement; } \\
\text { - the satisfaction in the fields: the condi- } \\
\text { tions of employment, facilities and ser- } \\
\text { vices, health and safety conditions } \\
\text { of work, job security-salaries and addi- } \\
\text { tional benefits, colleagues relations, } \\
\text { change management }\end{array}$ & $\begin{array}{l}\text { - } 1 \text { respondent systematically investigates } \\
\text { in surveys for the employees ( } 60 \% \text { of re- } \\
\text { spondents positively evaluate) } \\
\text { - } 1 \text { respondent conducts a study and stopped } \\
\text { its continuation } \\
\text { - } 3 \text { respondents do not provide the investigation }\end{array}$ \\
\hline \multirow[t]{3}{*}{$\begin{array}{l}\text { concentration } \\
\text { of work effects }\end{array}$} & $\begin{array}{l}\text { participation in training and the usefulness } \\
\text { training evaluation results }\end{array}$ & $\begin{array}{l}\text { all reported number of people are trained, } \\
\text { of which } 1 \text { respondent reported the number } \\
\text { of groups (professional: doctors, nurses } \\
\text { and administration staff) } \\
\text { nobody does not assess the usefulness of train- } \\
\text { ing }\end{array}$ \\
\hline & $\begin{array}{l}\text { the results of analysis of evaluation } \\
\text { and review staff }\end{array}$ & $\begin{array}{l}\text { - } 1 \text { respondent leads analysis of work } \\
\text { - } 1 \text { respondent carries out an assessment } \\
\text { of the employee and his direct supervisor re- } \\
\text { spondents do not conduct the assessment } \\
\text { and review of employees }\end{array}$ \\
\hline & $\begin{array}{l}\text { the level of absence and incidence, trends } \\
\text { in employment and staff rotation statistics }\end{array}$ & $\begin{array}{l}3 \text { respondents carry out an evaluation, } \\
\text { of which } 2 \text { perform the analysis in time }\end{array}$ \\
\hline
\end{tabular}

The CAF model has six specific criteria, which can assess the continuous quality improvement outputs. The statement of four practices identified in the $\mathrm{HCO}$ in this category is presented in Table 5.

The table shows that majority of the data (75\%) refers to the concentration of work effects. No HCO provided data on employee participation in the systems proposals to improve quality of care services. Do not are counted the indicators of employee participation in internal consultations and meetings of working groups, although all of the $\mathrm{HCO}$ declared to promote teamwork by creating task forces. This undermines the credibility of the answers given by the HCO. There is no employee involvement in matters of the company. There are no data on the number of employs involved in the initiatives (ideas, request, and enhancements). The interest in the opinions of managers of employees is low. Only one HCO carries out regular surveys of employees, of which $60 \%$ of the evaluation are positive. No assessment of the usefulness of training in all surveyed $\mathrm{HCO}$ indicates that the development of knowledge and skills to improve the quality level of health care services is neither managed nor controlled. Only one HCO conducts analysis of work (work efficiency, assessment skills, personality traits and behaviors), so assessment of the HPI is not a common practice. The study did not confirm hypothesis 3. Generally, it can be concluded, that quality improvement in health care services outputs in the analyzed criterion of $\mathrm{HCO}$ in the perspective of results in the relationship with employees is very low.

\subsection{Results of the activities in the relationship with customers - citizens (patients)}

External evaluation activities oriented on HPI are results of patient satisfaction survey. It can be assumed that the high results of internal evaluation of HPI determine high results of external evaluation. Patient satisfaction evaluation plays an important role in quality of health care services. 
Table 6. Description of practice in the category results of the activities in relations with customers - citizens (patients) (source: own research)

\begin{tabular}{|c|c|c|}
\hline \multirow[b]{2}{*}{ HPI rules } & Criterion CAF & Health care organizations $(\mathrm{HCO})-$ winners of PQA \\
\hline & $\begin{array}{l}\text { Results of the activities } \\
\text { in relations with patients }\end{array}$ & Number of practices \\
\hline $\begin{array}{l}\text { concentration } \\
\text { of work effects }\end{array}$ & $\begin{array}{l}\text { the actions undertaken } \\
\text { to make changes }\end{array}$ & $\begin{array}{l}\text { - } 4 \text { respondents carry out patient satisfaction survey } \\
\text { - } 3 \text { respondents describe the activities carried out on the basis } \\
\text { of the results } \\
\text { - } 1 \text { of the respondents leads continuously comparing the value } \\
\text { of the index patient satisfaction (general and by divisions } \\
\text { in the hospital) } \\
\text { - } 1 \text { of the surveyed uses different questionnaires for different } \\
\text { groups of patients (patients: in hospital divisions, specialist } \\
\text { clinics, diagnostic services) }\end{array}$ \\
\hline system approach & $\begin{array}{l}\text { activities undertaken for } \\
\text { building customer loyalty } \\
\text { and empower } \\
\text { of customer-citizen }\end{array}$ & $\begin{array}{l}\text { - } 4 \text { respondents do not inform patients of their rights } \\
\text { - } 1 \text { respondent publishes a document "Rights and obligations } \\
\text { of the patient" }\end{array}$ \\
\hline \multirow[t]{3}{*}{$\begin{array}{l}\text { results } \\
\text { of activities }\end{array}$} & $\begin{array}{l}\text { improving the quality and } \\
\text { accessibility } \\
\text { of information published }\end{array}$ & $\begin{array}{l}\text { - } 5 \text { respondents do not ask in the questionnaires for patients } \\
\text { for the information on quality of services } \\
\text { - } 3 \text { respondents availability has quantified }\end{array}$ \\
\hline & improving accessibility & $\begin{array}{l}\text { - } 1 \text { respondent extends the work time } \\
\text { - } 5 \text { respondents does not examine the medical services run-time }\end{array}$ \\
\hline & $\begin{array}{l}\text { improving support and } \\
\text { advice to the customer- } \\
\text { citizen and procedures } \\
\text { treatment of complaints }\end{array}$ & $\begin{array}{l}\text { - } 5 \text { respondents have Patients' Rights Ombudsman } \\
\text { - } 2 \text { respondents examines value of the complaints of patients } \\
\text { indicator over time and analyzes complaints } \\
\text { - } 1 \text { of the respondents reports court cases filed by patients }\end{array}$ \\
\hline
\end{tabular}

"Thus, the measurement of hospitals service quality has to be based on perceived quality rather than objective quality. It is because service quality is intangible, heterogeneous and its consumption and production occur in tandem" [13, p. 478]. In the self-assessment should be described the achievement of the organization relating to the results of measurements of satisfaction of citizens-clients (patients) and other measurements of the relationship with them. In the CAF model there are 5 specific criteria, which allow assess the foundations of continuous improvement quality outputs. All the practices identified in the HCO with the HPI rules are presented in Table 6 .

As the table shows all the practices refer to the principles of HPI. The vast majority of HCO conducts patient satisfaction surveys. The results of these studies in $80 \%$ are false, because:

- there are methodological faults in formulating of questions and answers scales,

- only $20 \%$ of the factors of quality in health care services (SERVQUAL) have been included in the questionnaire survey,
- there is a lack of comparative research of patients' opinions in relation with the opinion of others (physicians, medical staff-nurses, paramedics).

A positive phenomenon in the field of research is the diversity of patient satisfaction questionnaires, depending on the groups of patients (one HCO). Surveys conducted in most of the HCO are not permanent, so it is impossible to specify the parameters of quality of medical services most appreciated by patients. As the results of research, "the two dimensions most strongly positively associated with global satisfaction were receiving the expected medical help and being treated well by the doctor. To wait at the reception without getting information correlated negatively to patent satisfaction, and participation in the medical decision making correlated positively" [12, p. 86]. In the HCO there is a lack of knowledge about the impact of service quality factors on a global satisfaction of patients. In all examined HCO communication with the patient is not designed, managed, and improved. The distribution of information leaflets is limited. Call center activity (three HCO) is reduced to provide information on hours 
and days of receptions by physicians and to maintain records of the visit. Four respondents did not inform the patients of their rights. Only one HCO were observed as proactive in communication with patients. This is far from enough, because ,recent research shows that online communities can be a critical venue for knowledge sparring and transfer and has the potential to deliver socio-emotional support to patients, promote more active patient involvement in disease management, facilitate patient education and improve patient self-efficacy, which in turn leads to positive outcomes" [9, p. 124]. Additional, patient "participation in online health communities: has involved raising found to support research on specific diseases, sharing of innovate ideas to improve health care services, contributing to the development and the diffusion of public policies in health care" $[10$, p. 345$]$. Generally can be concluded, that all surveyed HCO have not created foundation for development of quality assessment and improvement activities in health care services. The study did not confirm the hypothesis 4 , because of the lack of reliable foundations for measurement and analysis.

\section{Conclusions}

All investigated HCO have certified QM system according to ISO 9001:2009, so it was assuming that the HPI is an integral part of the management system. This is due to connection QM principles set out in ISO 9000:2006 with QM system requirements set in ISO 9001:2008. As showed the studies, HRM is characterized by a low level of excellence. Important weaknesses in the functions and personnel actions limit the efficacy and efficiency of personnel management. It can also be stated that the rules of QM are not included in none of HCO in the QM system. Therefore, improving the efficiency of workers is rather accidental and has a very limited scope. Such a situation in HRM in studied $\mathrm{HCO}$ demonstrates that practice of meeting the needs and expectations of patients is not implemented. This causes also no grounds for improvement. Patient satisfaction with medical services is not a parameter in the system management of HCO. This may result from lack of knowledge management, or fear of the results of satisfaction surveys. Negative assessment carried out by patients could:

- force a change, and then induce the willingness and commitment to their implementation,
- challenge existing attitudes of doctors and medical staff to patients,

- verify the self-assessment of physicians and medical staff and hospital executives,

- reveal previously hidden problems (personal, organizational, managerial).

Generally, it should be pointed that the studied HCO have not fulfilled sufficient conditions to obtain the desired effects, directly or indirectly associated with the concept of HPI. Low level of medical services quality requires preparation and implementation of radical changes, which should start with improving the leadership effectiveness.

\section{Research implications}

The first research implication relates to the impact of QM on health care outcomes. Identification and characterization of the factors influencing change and improvement outputs can provide arguments for the implementation of the principles of quality in the HCO. Future research could provide a description of mechanisms for achieving the desired effect of improvement in care services outputs. The specificity of medical services requires the implementation of methods and tools used in QM, which can help analyze and evaluate the effectiveness and efficiency of activities.

The second research implication relates to the role of human factors in improving the quality of medical services and increasing efficiency. Appropriate practices HRM is the basis of HPI. Demonstrating the strength of his correlation by studies will allow the changes in management system of HCO. Impact of changes on the value of the index patient satisfaction should be measured. The results of research in this area will help determine the scale of the target values for these indicators.

The third research implication relates to the processes that affect desired quality assurance level in medical services. Identification of processes with their direct or indirect links affects patient satisfaction and is necessary to create a systematic approach in QM of medical services and implement both the principles of QM and HPI. The conclusions of the analysis process (internal, external) and the values of indicators can be the basis for conducting the benchmarking, as a part of continuous improvement. 
From a practical perspective, applications of improvement principles of QM into health care organization have influence on quality services level. In the practice "to see continuous quality improvement impact after the first year or two requires measuring specific areas where continuous quality improvement activities have been completed rather than looking at overall performance (...), hospitals using an analyzer (following an established sequence of steps) or prospector (more innovate in new program development) implementation approaches would experience a greater degree of continuous quality improvement implementation than those using other approaches" [1, p. 291]. However, the basis for quality improvement is the knowledge about activities and their results in internal and external relations. Therefore, the use of the EFQM model to assessment of the quality level of HCO is helpful for the implementation of changes aimed at improvement. Building awareness of quality management contributes to HCO creation of the need for management and the development of medical service personnel function. The results of studies presented might become an inspiration to carry out self-evaluation and exploration of sources to improve the quality of medical services.

\section{References}

[1] Carman J.M., Shortell S.M., Foster R.W., Hughes E.F.X., Boerstler H., O'Brien J.L., O’Connor E.J. Keys for Successful Implementation of Total Quality Management in Hospitals [in] Health Care Management Review, 35(4), 2010.

[2] Chou A.F., Vaughn T.E., McCoy K.D., Doebbeling B.N. - Implementation of Evidence - Based Practices: Applying a Goal Commitment Framework [in] Health Care Management Review, 36(1), 2011.

[3] de Korne D.F., Sol K., Van Wijngaarden J., Van Vliet E., Custers T., Cubbon M., Spileers W., Ygge J., Ang Ch., Klazinga N. - Evaluation of an International Benchmarking Initiative in Nine Eye Hospitals [in] Health Care Management Review, 35(1), 2010.

[4] Etchegaray J.M., St. John C., Thomas E.J. Measures and Measurement of High - Performance Work System in Health Care Setting: Propositions for Improvement [in] Health Care Management Review, 36(1), 2011.
[5] Ford-Eichoff K., Plowman D.A., McDaniel Jr. R.R. - Hospital Boards and Hospital Strategic Focus. The Impact of Board Involvement in Strategic Decision Making [in] Health Care Management Review, 36(2), 2011.

[6] Gowen Ch.R., Henagan S.C., McFadden K.L. Knowledge Management as a Mediator for the Efficacy of Transformational Leadership and Quality Management Initiatives in U.S. Health Care [in] Health Care Management Review, 34(2), 2009.

[7] Humphress R., Berge Z.L. - Justifying Human Performance Improvement Interventions [in] Performance Improvement, 45(7), 2006.

[8] Klimek D. - Quality of Medical Personnel Management (Based on the Example of Podlaskie Voivodeship) [in] Methods to improve the efficiency of workers (eds. E. Jędrych, J.P. Lendzion). Technical University, Lodz 2010.

[9] Nambisan P. - Evaluating Patient Experience in Online Health Communities: Implications for Health Care Organizations [in] Health Care Management Review, 36(2), 2011.

[10] Nambisan P. - Models of Customer Value Cocreation in Health Care [in] Health Care Management Review, 34(4), 2009.

[11] Otani K., Herrmann P.A., Kurz R.S. - Patient Satisfaction Integration Process: Are There any Racial Differences? [in] Health Care Management Review, 35(2), 2010.

[12] Rahmqvist M., Bara A.C. - Patent characteristics and quality dimensions related to patent satisfaction [in] International Journal for Quality in Health Care, 22(2), 2010.

[13] Rashid W., Jusoff H. - Service Quality in Health Care Setting [in] International Journal of Health Care, Quality Assurance, 22(5), 2009.

[14] Rathert Ch., Ishqaidef G., May D.R. - Improving Work Environments in Health Care: Test of a Theoretical Framework [in] Health Care Management Review, 34(4), 2009.

[15] Rudawska I. - Opieka zdrowotna. Aspekty rynkowe $i$ marketingowe. Wydawnictwo Naukowe PWN, Warszawa 2007.

[16] Szczepańska K. - Zarzq̨dzanie jakościq. W dązeniu do doskonatości. C.H. Beck, Warszawa 2011.

[17] Szczepańska K., Onyszczuk J., Essence of HPI Concept [in] Methods to improve the efficiency of workers (eds. E. Jędrych, J.P. Lendzion), Technical University, Lodz 2010. 